\title{
ON NONLINEAR PERTURBATIONS OF STURM-LIOUVILLE PROBLEMS IN DISCRETE AND CONTINUOUS SETTINGS
}

\author{
JEsús RODRÍGUEZ AND ADAM J. SUAREZ
}

\begin{abstract}
In this paper we provide sufficient conditions for the existence of solutions to certain classes of second-order discrete and continuous systems. In particular, we examine problems that can be posed as nonlinear perturbations of Sturm-Liouville problems. We first provide a lemma on the invertibility of a nonlinearly-perturbed invertible linear operator, and apply this result to extend previous work on these topics.
\end{abstract}

Mathematics subject classification (2010): 34B24, 34L30, 39A12, 39A99, 47H09, 47H10.

Keywords and phrases: Sturm-Liouville Problems, ordinary differential equations, difference equations, nonlinear equations.

\section{REFERENCES}

[1] R.P. Agarwal, On multipoint boundary value problems for discrete equations, Journal of Mathematical Analysis and Applications, 96, 2 (1983), 520-534.

[2] B. AHMAD, J.J. NIETO, Existence of solutions for nonlocal boundary value problems of higher-order nonlinear fractional differential equations, Abstract and Applied Analysis, 2009 (2009).

[3] M.A. AL-GWAIZ, Sturm-Liouville theory and its applications, Springer-Verlag, London, 2008.

[4] J. BEHRNDT, Elliptic boundary value problems with $\lambda$-dependent boundary conditions, Journal of Differential Equations, 249, 11 (2010), 2663-2687.

[5] M. Benchohra, J.J. Nieto, A. Ouahab, G. Infante, Second-order boundary value problem with integral boundary conditions, Boundary Value Problems, 2011, 15 (2010).

[6] A. Boucherif, Nonlinear three-point boundary value problems, Journal of Mathematical Analysis and Applications, 77, 2 (1980), 577-600.

[7] K. BROWN, Nonlinear boundary value problems and a global inverse function theorem, Annali di Matematica Pura ed Applicata, 106, 1 (1975), 205-217.

[8] K. BRown, S. Lin, Periodically perturbed conservative systems and a global inverse function theorem, Nonlinear Analysis: Theory, Methods \& Applications, 4, 1 (1980), 193-201.

[9] Y.K. CHANG, J.J. NiETO, Existence of solutions for impulsive neutral integro-differential inclusions with nonlocal initial conditions via fractional operators, Numerical Functional Analysis and Optimization, 30, 3-4 (2009), 227-244.

[10] K. Deimling, Nonlinear Functional Analysis, Springler-Verlag, Berlin, 1985.

[11] C.L. Dolph, Nonlinear integral equations of the hammerstein type, Transactions of the American Mathematical Society, 66 (1949), 289-307.

[12] P. DrÁBeK, J. Milota, Methods of Nonlinear Analysis: Applications to Differential Equations, Birkhäuser Verlag AG, Basel, 2007.

[13] D.L. ETheridge, J. RodríGueZ, Periodic solutions of nonlinear discrete-time, Applicable Analysis, 62, 1-2 (1996), 119-137.

[14] D.L. ETheridge, J. Rodríguez, Scalar discrete nonlinear two-point boundary value problems, Journal of Difference Equations and Applications, 4, 2 (1998), 127-144.

[15] M. Feng, X. Zhang, X. YAng, Positive solutions of nth-order nonlinear impulsive differential equation with nonlocal boundary conditions, Boundary Value Problems, 2011 (2011), 1-19.

[16] J.R. Graef, L. Kong, Multiple Solutions of Boundary Value Problems: A Variational Approach, Trends in Abstract and Applied Analysis. World Scientific, 2015. 
[17] I. KigURADZE, J. ŠREMR, Solvability conditions for non-local boundary value problems for twodimensional half-linear differential systems, Nonlinear Analysis: Theory, Methods \& Applications, 74, 17 (2011), 6537-6552.

[18] E. LANDESMAN, A. LAZER, ET AL., Linear eigenvalues and a nonlinear boundary value problem, Pacific Journal of Mathematics, 33 (1970), 311-328.

[19] A. LAZER, D. SÁNCHEZ, ET AL., On periodically perturbed conservative systems, The Michigan Mathematical Journal, 16, 3 (1969), 193-200.

[20] A.C. LAZER, D.E. LEACH, On a nonlinear two-point boundary value problem, Journal of Mathematical Analysis and Applications, 26, 1 (1969), 20-27.

[21] D. LEACH, On Poincaré's perturbation theorem and a theorem of WS Loud, Journal of Differential Equations, 7, 1 (1970), 34-53.

[22] J. RodRíGUEZ, Nonlinear differential equations under Stieltjes boundary conditions, Nonlinear Analysis: Theory, Methods \& Applications, 7, 1 (1983), 107-116.

[23] J. RodrígueZ, On resonant discrete boundary value problem, Applicable Analysis, 19, 4 (1985), 265-274.

[24] J. RodRígueZ, On nonlinear discrete boundary value problems, Journal of Mathematical Analysis and Applications, 114, 2 (1986), 398-408.

[25] J. RODRÍGUEZ, Galerkin's method for ordinary differential equations subject to generalized nonlinear boundary conditions, Journal of Differential Equations, 97, 1 (1992), 112-126.

[26] J. RodRíGueZ, Nonlinear discrete sturm-liouville problems, Journal of Mathematical Analysis and Applications, 308, 1 (2005), 380-391.

[27] J. RodríGueZ, Z. ABERnATHy, Nonlinear discrete sturm-liouville problems with global boundary conditions, Journal of Difference Equations and Applications, 18, 3 (2012), 431-445.

[28] J. Rodríguez, Z, Abernathy, On the Solvability of Nonlinear Sturm-Liouville Problems, Journal of Mathematical Analysis and Applications, 387, 1 (2012), 310-319.

[29] J. Rodríguez, D. SweEt, Projection methods for nonlinear boundary value problems, Journal of Differential Equations, 58, 2 (1985), 282-293.

[30] J. RodríGUEZ, P. TAYLOR, Scalar discrete nonlinear multipoint boundary value problems, Journal of Mathematical Analysis and Applications, 330, 2 (2007), 876-890.

[31] J. RODRÍGUEZ, P. TAYLOR, Weakly nonlinear discrete multipoint boundary value problems, Journal of Mathematical Analysis and Applications, 329, 1 (2007), 77-91.

[32] J. RODRÍGUEZ, P. TAYLOR, Multipoint boundary value problems for nonlinear ordinary differential equations, Nonlinear Analysis: Theory, Methods \& Applications, 68, 11 (2008), 3465-3474.

[33] M. V̈̈тн, Bifurcation for a reaction-diffusion system with unilateral obstacles with pointwise and integral conditions, Nonlinear Analysis: Real World Applications, 12, 2 (2011), 817-836.

[34] Z. ZHAO, J. LiANG, Existence of solutions to functional boundary value problem of second-order nonlinear differential equation, Journal of Mathematical Analysis and Applications, 373, 2 (2011), 614-634. 